\title{
Perlindungan Hukum terhadap Tersangka dalam Perspektif Hak Asasi Manusia
}

\author{
Harmaji Riswinarno ${ }^{1}$, Teguh Suratman ${ }^{2}$
}

${ }^{1}$ Harmaji Riswinarno; Fakultas Hukum Universitas Merdeka Malang; Jl. Terusan Dieng No.62-64; Malang; 65115; Indonesia.

${ }^{2}$ Teguh Suratman; Fakultas Hukum Universitas Merdeka Malang; Jl. Terusan Dieng No.62-64; Malang; 65115; Indonesia.

\section{ART I C LEINFO}

Article history:

Received 2018-02-22

Received in revised form

2018-03-04

Accepted 2018-06-01

Kata kunci:

Perlindungan Hukum, Hak Asasi

Manusia, Tersangka..

Keywords:

Human Rights, Legal Protection, Suspect.
Corresponding Author:

Harmaji Riswinarno

E-mail address: diah_Iwg@yahoo.com

DOI: https://doi.org/10.26905/idjch.v9i1.2203

\section{Abstrak}

Penelitian ini tentang perlindungan hukum dalam perspektif Hak Aasasi Manusia tersangka dan potensi pelanggaran pada penyidikan perkara pidana.Adapun tujuan adalah untuk perlindungan hak asasi tersangka, menjamin kepastian hukum serta menghindari perlakuan sewenang-wenang, serta mengetahui kendala-kendalanya. Penelitian ini merupakan penelitian hokum empiris. Lokasi penelitian di Polres Sidoarjo. Analisis data menggunakan deskriptif kualitatif, dengan menggunakan teknik analisis isi.Perlindungan hukum hak tersangka pada penyidikan perkara pidana dapat terwujud dengan baik apabila ada komitmen untuk menegakkan hukum dengan sungguh-sungguh, serta masyarakat ikut memberikan control untuk mengurangi potensi pelanggaran Hak Asasi Manusia. Dalam Undang-Undang Nomor 8 Tahun 1981 tentang Kitab Undang-Undang Hukum Acara Pidana sebagai dasar pijakannya, proses pemeriksaan di Polres Sidoarjo, penyidik dalam hal penyelidikan terhadap tersangka memperhatikan hak asasinya, memberi kebebasan menggunakan Penasihat Hukum, member kebebasan pada waktu menjawab pertanyaan penyidik, tidak melakukan penekanan pada waktu melakukan pemeriksaan, memberitahukan kepada penasehat hokum atau keluarga apabila tersangka sakit dalam tahanan, memperlakukan dengan baik saat penyidikan.

\section{Abstract}

This research is about legal protection in the perspective of human rights rights of suspects and potential violations in criminal case investigations. The purpose is to protect the rights of suspects, ensure legal certainty and avoid ill-treatment, and know the obstacles. This research is an empirical legal research. Research location at Sidoarjo Regional Police Station. Data analysis using descriptive qualitative, us- 
ing content analysis techniques. Legal protection of suspect rights in criminal case investigations can be realized properly if there is a commitment to enforce the law seriously, and the community also provides control to reduce potential human rights violations. In Law Number 8 of 1981 concerning the Criminal Procedure Code as a basis, the examination process at the Sidoarjo Regional Police, investigators in the case of investigations of suspects pay attention to their human rights, give freedom to use a Legal Advisor, give freedom when answering investigator questions, do not emphasize when conducting examinations, notify legal counsel or family if the suspect is ill in custody, treats well when investigating.

\section{Latar Belakang}

Praktek kurang penghargaan Hak Asasi Manusia, dalam masyarakat banyak dijumpai indikatornya dari waktu ke waktu lembaga Pemasyarakatan tidak pernah sepi dari para warga binaan, bahkan dihampir semua Lembaga Pemasyarakatan penghuninya semakin bertambah, sehingga Lembaga Pemasyarakatan sering over capasity. Begitu mudahnya Polisi menetapkan sesorang menjadi berstatus tersangka. Tersangka adalah sebutan untuk mereka yang diduga melakukan suatu tindak pidana. Walaupun dugaan melakukan tindak pidana cap/stigma yang buruk dan negatif, bukan berarti seseorang bisa diperlakukan dengan melanggar hak asasinya. Biar bagaimanapun seorang tersangka pelaku tindak pidana memiliki hak asasi, dengan kata lain, memiliki hakhak yang harus dipenuhi juga secara hukum. "Dalam sistem peradilan pidana, ketentuan perlindungan terhadap hak asasi tersangka, terdakwa dan terpidana, dan narapidana mengarah pada kewajiban utama Negara melalui Hukum Acara Pidana agar sejalan dengan itujuan dari Hukum Acara Pidana, yaitu untuk mewujudkan dan menjamin kebenaran sesuai dengan perikemanusiaan (Siregar, 1983).

Sementara itu, kesadaran hukum masyarakat dan penegak hukum yang rendah berkaitan dengan kualitas sumber daya di lembaga-lembaga yang tergabung dalam sistem peradilan pidana, telah menimbulkan kesenjangan antara kesadaran hukum (law awareness), tingkah laku hukum (law behavior) lembaga-lembaga peradilan pidana. Pada akhirnya, kesenjangan ini melahirkan praktikpraktik penegakan yang represif, seperti penyiksaan, penekanan dan intimidasi dalam penyidikan, padahal cara-cara seperti itu dilarang oleh Pasal 117 ayat (1) KUHAP berbunyi sebagai berikut: Keterangan tersangka idan atau saksi kepada penyidik diberikan tanpa tekanan idari siapapun dan atau dalam bentuk apapun.

Indikator ketidakberhasilan dalam menegakkan hukum, akibat penyalahgunaan kekuasaan di kalangan penegak hukum dalam suatu perkara pidana sesungguhnya disadari oleh Pemerintah maupun para penegak hukum. Di dalam UndangUndang No. 8 Tahun i1981 tentang Hukum Acara Pidana belum memberikan jaminan optimal untuk melindungi hak asasi tersangka, terdakwa dan terpidana.

Upaya memberikan perlindungan HAM termasuk diantaranya hak-hak tersangka, di Indonesia merupakan kehendak Undang-Undang Dasar Negara Republik Indonesia 1945 dan peraturan perundang-undangan, dan UU tentang HAM mengamanatkan hal tersebut. Reformasi yang bergulir semakin memantapkan tekad Indonesia dalam penghargaan terhadap HAM. UUD NRI 1945 yang awalnya hanya memuat beberapa jaminan perlindungan HAM kemudian dilengkapi 
dengan beberapa perubahan yang merumuskan HAM dalam bab tersendiri. Dengan disahkannya Undang-Undang Nomor 39 tahun 1999 tentang HAM dan Undang-Undang Nomor 26 tentang Pengadilan HAM maka landasan hukum bagi upaya perlindungan HAM di Indonesia semakin kokoh dan kuat dari sisi hukum. Atas dasar uraian problematika latar belakang diatas, maka dalam penelitian ini menekankan pada hal-hal yang terkait dengan perlindungan hukum atas hak asasi tersangka.

Tujuan penelitian ini adalah untuk mengetahui dan menganilisis bentuk perlindungan ihukum terhadap tersangka di Polres Sidoarjo dalam perspektif HAM serta untuk mengetahui dan menganalisis kendala-kendala yang dihadapi oleh Polres Sidoarjo dalam memberikan perlindungan hukum terhadap tersangka.

\section{Metode}

Jenisi penelitian ini adalah termasuk dalam katagori penelitian empiris yakni penelitian iyang mengkaji fakta empirik berhubungan dengan peraturan perundang-undangan yang berlaku dalam masyarakat (Wignyosoebroto, 1995). Dalam hal ini hukum sebagai norma positif yang berlaku pada suatu waktu tertentu dan diterbitkan sebagai produk suatu kekuasaan politik tetentu yang memiliki legitimasi.

Penelitian ini supaya memperoleh pemahaman yang lebih berbobot, maka mempergunakan pendekatan yuridis sosiologis/empiris untuk mengetahui penerapan ketentuan-ketentuan hukum di lapangan, sehingga aspek kepentingan hak-hak masyarakat dilindungi secara baik.

Metode analisis idata yang dipergunakan dalam penelitian ini adalah metode normatif dalam optik preskreptif. Dengan penalaran deduktifinduktif untuk menghasilkan proposisi atau konsep sebagai jawaban permasalahan atau hasil/ temuan penelitian. Analisis data dengan meng- gunakan metode deskriptif analisis, yaitu dengan menggambarkan atau memaparkan secara jelas kondisi dan kenyataan dilapangan tentang konsistensi pelaksanaan kepolisian terhadap proses penyidikan dalam perlindungan HAM.

\section{Pembahasan}

\subsection{BentukiPerlindungan HAM Terhadap Tersangka Dalam Proses Pemeriksaan di Polres Sidoarjo}

Berdasarkan asas praduga tak bersalah, kedudukan Tersangka adalah pihak yang dirampas hak-haknya adalah tidaki adil apabila ikerugian akibat perampasan hak itersebut masih iharus ditambah dengan kewajiban pembuktian olehnya (Widhayanti, 1998).

Berikut ini penulis sampaikan pendangan dan pendapat tentang penerapan ketentuan Pasal 56 ayat (1) KUHAP, yang menegaskan bahwa hak tersangka atau terdakwa didampingi penasehat hukum apabila tindak pidana yang disangkakan atau didakwakan diancam dengan pidana mati atau iancaman pidana 15 tahun atau lebih atau bagi yang tidak mampu yang diancam dengan pidana 5 tahun atau lebih yang tidak mempunyai penasehat hukum sendiri, pejabat yang bersangkutan dalam proses peradilan wajib menunjuk penasehat hukum bagi mereka.

Ketentuani Pasal 56 ayat (1) KUHAP dari segi pendekatan Strict Law atau Formalistic Legal Thinking mengandung berbagai aspek permasalahan hukum. Dimana setiap tersangka berhak didampingi penasehat hukum dalam semua tingkat pemeriksaan. Hak ini sesuai dengan deklarasi universal HAM yang menegaskan hadirnya penasehat hukum mendampingi tersangka merupakan nilai yang inhaerent pada diri manusia. Dengan demikian mengabaikan hak ini bertentangan dengan nilai HAM. Sehingga pemenuhan atas hak ini dalam proses peradilan pada semua tingkat pemeriksaan menjadi kewajibanidari pejabat yang bersangkutan. Apabila tindak pidana yang disangkakan atau 
didakwakan, diancam dengan pidana mati atau 15 tahun atau lebih, atau bagi yang tidak mampu yang diancam dengan pidana 5 tahun atau lebih, yang tidak mempunyai penasehat hukum.

Terkait dengan itu, pejabat yang bersangkutan dalam semua tingkat pemeriksaan wajib menunjukipenasehat hukum bagi mereka. Berdasarkan ketentuan HAM Pasal 52 (1) KUHAP, kehadiran dan keberadaan penasehat hokum bersifat imperatif, sehingga mengabaikannya mengakibatkan hasil pemeriksaan itidak sah idan batal idemi ihukum.

Dalam Pasal 56 KUHAP sebagai ketentuan yang bernilai HAM telah diangkat imenjadi salah isatu patokan Miranda ruleiatau Mirandai principle. Apabila pemeriksaan penyidikan, penuntutan atau persidangan tersangka atau terdakwa tidak didampingi penasehat hukum, maka sesuai dengan Miranda rule, pemeriksaan itidak sah i(ilegal) atau batal demi hukum (null iand void).

Standari "Miranda rule" inilah yang ditegakkan dalam Putusan MA No.1565 K/Pid/ 1991 (16 septemberi 1993) yang menyatakan: "apabila isyarat syarat ipermintaan tidak dipenuhi sepertii halnya penyidik tidak menunjuk penasehat hukum bagi tersangka sejaki awal penyidikan, tuntutan penuntut umum dinyatakan tidak idapat iditerima".

\subsection{Upaya Hukum yang Dilakukan Tersangka Jika Hak-Haknya Dilanggar dalam Proses Penyidikan di Polres Sidoarjo.}

Berdasarkan data hasil penelitian yang penulis dapatkan dari lokasi penelitian, bahwa upaya ihukum yang sering dilakukan oleh pihak tersangka yang merasa hak asasi manusianya dilanggar adalah sebagai berikut: Permohonan perlindungan hukum dalam hal ini menyangkut perlindungan terhadap diri tersangka dari tindakan kekerasan dalam bentuk apapun dan atau oleh siapapun, termasuk di dalamnya perlindungan ter- hadap ancaman yang dapat membahayakan jiwa tersangka itu sendiri.

1. Permohonan gelar perkara.

Permohonan gelar perkara ini merupakan salah satu upaya yang dalam praktiknya tidak umum, biasanya permohonan gelar perkara ini diajukan oleh penasehat hukum karena pada umumnya upaya ini diajukan apabila perkara pidana yang sedang diperiksa penyidik dirasa bukan merupakan ranah hukum pidana melainkan masuk dalam ranah hukum perdata dengan kata lain penyidik telah salah menerapkan hukumnya dan terkesan memaksakan hukumnya.

2. Praperadilan.

Penyidik dalam hal memeriksa tersangka harus berpedoman pada peraturan perundang-undangan yang berlaku, berdasarkan analisis penulis pelanggaran terhadap hak asasi tersangka pada saat penyidikan dapat terjadi akibat dari kurangnya pemahaman petugas penyidik perkara terhadap peraturan perundang-undangan yang berlaku disamping itu tindakan diskresi kepolisian juga ikut menentukan pelanggaran hak asasi tersangka.

3. Permohonan perlindungan hukum yang dilakukan tersangka.

Permohonan perlindungan hukum yang dilakukan tersangka apabila hak - haknya dilanggar tersangka dapat meminta bantuan penasihat hukum, dapat meminta perlindungan kepada Departemen hukum dan HAM, dapat melakukan penolakan terhadap hasil pemeriksaan apabila terjadi penekanan atau arogansi pada waktu dilakukan pemeriksaan yang dilakukan oleh pihak kepolisian.

4. SP3 (Surat Pemberitahuan Penghentian Penyidikan) sebagai Perlindungan HAM kepada tersangka.

SP3 adalah salah satu bentuk tindakan atau instrumen konkret penyidik dalam memutuskan apakah suatu perkara yang dilaporkan te- 
lah memenuhi syarat hukum yaitu ada bukti permulaan yang cukup atau tidak. Sehingga penggunaannya dapat melindungi hak-hak asasi tersangka. Mencapai harapan terhadap tujuan penelitian maka dilakukan pendekatan secara yudiris sosiologis yaitu dengan melakukan pembahasan yang didasarkan pada ketentuan peraturan perundang-undangan yang berlaku dan dikaitkan dengan teori hukum serta dengan melihat realita masyarakat di Polresta Sidoarjoidalam menjalankan tugas dan ifungsinya sebagai ipenegak hukum khususnya iserta upaya dan hambatan peningkatan kinerja kepolisian tersebut.

\subsection{Perlindungan Hukum Terhadap Tersangka Di Polres Sidoarjo.}

Untuk dapat di katakan Pelaksanaan peraturan perundangan-undangan efektif, diberlakukan dalam realitas kehidupan masyarakat, maka perlu adanya Substansi hukum, Penegak Hukum, Budaya Masyarakat, dan Infrakstruktur (Sarana prasarana) serta, Perilaku Penegak hukum yang sejalan serta saling menunjang satu sama lain.

1. Substansi Hukum dalam pelaksanaan Pasal 13 huruf c Undang-Undang No. 2 Tahun 2002 tentang kepolisian berkaitan tentang akuntabilitas dan transparasi dalam penyidikan melalui pemberian SP3 sebagai upaya perlindungan HAM Tersangka.

Perlindungan HAM dalam proses penyidikan tentunya diikuti dengan perbaikan kualitas pelayanan aparatur pemerintah dan penegak hukum pada proses penyidikan. Kepolisian Negara Republik Indonesiaimerupakan salah satu aparatur negara yang mempunyai peran penting dalam menjaga keamanan dan ketertiban masyarakat, dan tidak hanya dilihat dari sudut pandang pelayanan saja, akan tetapi dikarenakan peran Kepolisian menjaga keamanan dan ketertiban masyarakat sesuai dengan Pasal 2, Undang-Undang No. 2 Tahun
2002 tentang Kepolisian, dimana dirumuskan bahwa Kepolisian mempunyai tugas pengayom, pelindung dan pelayan masyarakat sebagai salah satu lembaga dalam penyelenggaraan HAM.

Kepolisian memiliki peranan penting untuk memberikan suatu perlindungan hukum terhadap masyarakat, Kepolisian merupakan salah satu unsur penegak hukum yang mempunyai itugas dan wewenang yang diatur dalam Undang-Undang iNo. 2 Tahun 2002 itentang Ketentuan-Ketentuan Pokok Kepolisian Negara, maupun UU No.8 itahun 1981 itentang Undang-Undang Hukum iAcara Pidana atau lebih dikenal sebagai KUHAP, terkait dengan ini wewenang Kepolisian Negara dalam penyidikan suatu perkara yang terjadi dalam masyarakat.

Dalam penyidikan dan penyelidikan yang dilakukan oleh kepolisian merupakan pelaksanaan tugas dan wewenangnya, dalam menjalankan tugasnya dituntut lebih bersifat akuntabel dan transparan, utamanya dalam proses penyelidikan dan penyidikan.

Berkaitan dengan substansi hukum yang berkaitan dengan pelaksanaan tugas dan fungsi pokok kepolisian untuk memberikan perlindungan, pengayoman idan pelayanan kepada imasyarakat, dimana hal itersebut dapat dikategorikan sebagai bentuk perlindungan HAM, khususnya dalam kaitannya dengan akuntabilitas dan transparansi penyidikan melalui SP3, dimana terdapat kompleksitas terhadap peraturan perundang-undangan yang mengatur itentang pelaksanaan tugas dan fungsi pokok kepolisian dalam penyidikan yang akuntabel dan transparan melalui pemberian SP3, dimana peraturan tersebut disusun secara sistematis mulai dari KUHAP sampai dengan PerKapolri No. 8 Tahun 2009 tentang Implementasiiprinsip dan standar HAM dalam penyelenggaraan itugas Kepolisian RI, akan tetapi dalam sosialisasi PerKap tersebuti kurang di- 
pahami oleh sebagian jajaran penyidik di Polres Sidoarjo.

2. Penegak Hukum

Berkenaan dengan perlindungan hukum pada penegak hukum yang kongkritnya khusus dalam penelitian ini, penegak ihukum yang dimaksud adalah penyidik di Polres Sidoarjo. Adapun standarisasi penegakan hukum menurut peneliti adalah: 1) sampai sejauh mana petugas mempunyai pemahaman terhadap peraturan perundang-undangan dan terikat oleh iperaturan yang ada, 2) sampai batas imana petugas idiperkenankan memberikan "kebijaksanaan", 3) sampai sejauh mana derajat sinkronisasiipenugasan yang diberikan kepada ipara petugas,isehingga memberikan batasan yang tegas pada wewenangnya.

Apabila merujuk pada hasil wawancara yang diperoleh peneliti, khususnya dalam pemahaman terhadap peraturan perundangundangan yang berkaitan dengan tugas dan fungsi pokok kepolisian pada proses penyidikan yang akuntabel dan transparan tentunya berbanding terbalik dengan apa yang diharapkan peneliti, bahwa sebagian besar penyidik di Polres sidoarjo tidak mengetahui dan memahami secara konkrit terhadap landasan hukum yang berkaitan dengan akuntabilitas dan transparansi penyidikan dalam upaya perlindungan HAM, sehingga apabila penyidik tidak menjalankan tugas dan fungsi sebagai penyidik, maka pimpinan tidak segen untuk melakukan tindakan yang berkaitan dengan kebijaksanaan terhadap sanksi yang diperoleh, apabila hal tersebut sudah dilakukan penelitian lebih lanjut dan sudah dilakukan teguran kepada mereka maka, pimpinan berhak memberika kebijakan untuk diproses sesuai dengan peraturan perundang-undangan yang ada.

3. Budaya masyarakati dalam pelaksanaan Pasal 13 huruf C UU No. 2 Tahun 2002 tentang kepolisian berkaitan tentang akuntabilitas dan transparansi dalam penyidikan melalui pemberian SP3 sebagai upaya perlindungan HAM Tersangka.

Berkenan dengan proses perlindungan hukum pada budaya imasyarakat adalah sedikit banyak adapun imenyangkut masalah derajat kepatuhan atau kesadaran hukum. Standarisasi efektifitas warga masyarakat yang sempit bahwa derajat kepatuhann atau kesadaran hukum masyarakat terhadap hukum merupakan isalah satu indicator berfungsi efektifihukum iyang bersangkutan.

Konsep ini berkaitan dengan aspek-aspek kognitif dan perasaan yang sering kali dianggap sebagai faktor-faktor yang mempengaruhi ihubungan antara hokum dengan polapola perilaku manusia dalam masyarakat. Setiap masyarakat senantiasa mempunyai kebutuhan-kebutuhaniutama atau dasar dan para warga masyarakat menetapkan pengalamanpengalaman tentang faktor-faktor yang mendukung dan yang mungkin menghalang-halangi usahanya untuk memenuhi kebutuhan utama atau dasar tersebut. Apabila factor-faktor tersebut dikonsolidasikan, maka terciptalah system nilai-nilai yang mencakup konsepsikonsepsi atau patokan-patokan abstrak tentang apa yang dianggap baik dan apa yang dianggap buruk.

Hukum merupakan kontribusi daripada sistem nilai-nilai yang berlaku di dalam masyarakat. Dengan demikian nyatalah bahwa masalah kesadaran hukum sebenarnya masalah nilainilai. Maka kesadaran hokum adalah konsepsi abstrak di dalam diri imanusia, tentang keserasian antara ketertiban dengan ketentraman yang dikehendaki atau yang sepantasnya dalam pelaksanaan Pasal 13 huruf C UU No. 2 Tahun 2002 tentang Kepolisian berkaitan tentang akuntabilitas dan transparansi dalam penyidikan melalui pemberian SP3 sebagai upaya perlindungan HAM. 
4. Infrastruktur dalam pelaksanaan Pasal 13 huruf C UU No.2 Tahun 2002 tentang kepolisian berkaitan tentang akuntabilitas data transparansi dalam penyidikan melalui pemberian SP3 sebagai upaya perlindungan HAM Tersangka.

Dalam pelayanan penyidikan banyak dilakukan dengan media elektronik yaitu dengan komputer, dimana dalam pengoperasiannya membutuhkan aliran listrik, dikarenakan banyaknya pemadaman bersama, jika listrik padam, maka pelayanan penyidikan berhenti total, hal tersebut ditengarahi bahwa Polres sidoarjo tidak mempunyai Genset (pembangkit listrik) sendiri.

5. Perilaku penegak hukum dalam pelaksanaan akuntabilitas dan transparansi dalam penyidikan melalui pemberian SP3 sebagai upaya perlindungan HAM Tersangka.

Perilaku hukum, seseorang berperilaku sesuai dengan tingkat kesadaran yang tinggi. Buktinya adalah bahwa yang bersangkutan patuh atau taat pada hukum. Dengan demikian dapat dikatakan bahwa tinggi rendahnya tingkat kesadaran ihukum akan dapat dilihat dari derajat kepatuhan hukum yang terwujud idalam pola iperilaku manusia yang nyata.

Tingkat pengetahuan hukum dan tingkat pemahaman hukum sebagian besar penyidik Polres Sidoarjo dapat dikatakan kurang cukup memadai, sehingga akan berpengaruh pada tingkat menentukan sikap hukum terkait dengan pelaksanaan Pasal 13 huruf C UU No. 2 Tahun 2002 tentang Kepolisian yang berkaitan dengan akuntabilitas dan transparansi penyidikan melalui pemberian SP3 sebagai upaya perlindungan HAM.

\subsection{Pemberian Bantuan Hukum Secara Cuma- Cuma Mendukung Perlindungan Hukum Tersangka.}

Apabila tindak pidana yang disangkakan atau didakwakan diancam dengan pidana mati atau 15 itahun atau lebih, atau bagi yang tidak mampu yang diancam dengan ipidana 5 tahun atau lebih, yang tidak imempunyai penasehat hukum, maka pejabat yang bersangkutan dalam semua tingkat pemeriksaan wajib menunjuk penasehat hukum bagi mereka. Berdasarkan Pasal 52 (1) KUHAP, kehadiran dan keberadaan ipenasehat hukum bersifat imperatif, sehingga mengabaikannya mengakibatkan hasil ipemeriksaan tidak sah dan batal demi ihukum.

Hasil penelitian yang penulis temukan, bahwa ada tersangka yang tidak didampingi oleh penasehat hukum disebabkan karena penyidik tidak menawarkan bantuan pendampingan penasehat hukum secara cuma-cuma atau tanpa dipungut biaya, bisanya penyidik mengarahkan tersangka untuk didampingi oleh penasehat hukum yang sudah disiapkan oleh penyidik. Penyidik juga mengatakan bahwa pendampingan tersebut juga harus memberikan insentif dalam bentuk uang transport kepada seorang pengacara, sehinggga kondisi yang demikian, berakibat tersangka tidak mau didampingi oleh pengacara.

Di Inggris ada keseimbangan antara kebebasan penyidik (polisi) untuk bertanya kepada siapa saja tersangka atau bukan yang dianggap dapat memberikan keterangan yang berguna dan hak tersangka untuk tidak menjawab, namun demikian, menurut Patrick Devlin, di Inggris selama ini tetap ada anggapan umum bahwa lebih baik menjawab pertanyaan yang diberikan oleh polisi dari pada tidak menjawab, karena hal tersebut akan merugikan sendiri (Devlin, 1996).

Di Polres Sidoarjo tidak ada satupun tersangka yang diperiksa oleh penyidik yang tidak memilih diam, karena menurut penulis jika tersangka memilih hak untuk diam tidak melayani pertayaan dari pada penyidik ada sebagian penyidik yang akan melakukan pemeriksaan dengan cara kekerasan terhadap tersangka tersebut. Tindakan penyidik tersebut merupakan bentuk pelanggaran hak asasi manusia kepada tersangka. Dengan dikeluar- 
kannya Peraturan Peradi Nomor 1 Tahun 2010 Tentang Petunjuk Pelaksanaan Pemberian Bantuan Hukum secara Cuma-Cuma, maka proses pemberian perlindungan hukum terhadap tersangka di Polres sidoarjo menjadi lebih baik.

\subsection{Kendala-Kendala yang Dihadapi Dalam Memberikan Perlindungan Hukum}

Kendala-kendala ini dapat dikelompokkan menjadi kendala internal dari penyidik Polres sidoarjo dan kendala eksternal dari Polres Sidoarjo, adalah sebagai berikut: Berasal dari Internal Penyidik Polres Sidoarjo; Kurangnya kesadaran hukum penyidik Polres Sidoarjo; Sarana dan prasarana kurang memadai; Kurangnya koordinasi yang baik dengan instansi lain yang terkait. Aspek eksternal Polresta Sidoarjo: Kurangnya kesadaran hukum masyarakat; Radius tempat tinggal tersangka yang terlalu jauh; Alamat tersangka yang tidak lengkap.

\subsection{Upaya-upaya Penanggulangan yang Dilaku- kan Pihak Polres Sidoarjo dalam Mengatasi Kendala-Kendala sebagai Upaya Perlindungan HAM.}

Upaya penanggulangan terhadap faktorfaktor kendala dalam pelaksanaan Pasal 13 huruf c UU No. 2 Tahun 2002 tentang Kepolisian yang berkaitan dengan akuntabilitas dan transparansi pada proses penyidikan melalui SP3 sebagai upaya perlindungan HAM antara lain adalah Meningkatkan kesadaran hukum.

Indikator-indikator dari kesadaran hukum merupakan petunjuk yang konkrit terhadap adanya taraf kesadaran hukum tertentu. Dengan adanya indikator tersebut, seseorang yang menaruh perhatian pada kesadaran hukum akan dapat mengetahui apa yang sesungguhnya merupakan kesadaran hukum. Pembinaan Anggota Polisi: Pendidikan Formal; Pendidikan Non Formal; Penerapan Pengawasan Terhadap Penyidik; Peningkatan Sarana dan Prasarana; Meningkatkan Koordinasi dengan Instansi Lain; Peningkatan anggaran perencanaan penanganan tindak pidana.

Sedangkan, dalam aspek eksternal, terdapat beberapa Kendala-kendala yang berkenaan dengan kesadaran hukum, maka menurut hemat peneliti perlu dilakukan sosialisasi terhadap penerapan Pasal 13 huruf C Undang-Undang No. 2 Tahun 2002 tentang Kepolisian tentang perlindungan HAM melaui transparansi penyidikan dalam pemberian SP3, maka hal-hal konkrit dalam hal sosialisasi tersebut berkenaan antara lain: perlunya peningkatan kerjasama antara polisi dan masayarakat sebagai upaya penerapan Pasal 13 huruf C UU No. 2 Tahun 2002 tentang Kepolisian, perlindungan HAM melaui transparansi penyidikan dalam pemberian SP3 melalui proses sosiaslisasi dengan masyarakat guna meningkatkan pengetahuan dan pemahaman masyarakat terhadap peraturan perundang-undangan yang berkaitan dengan penerapan Pasal 13 huruf C UU No. 2 Tahun 2002 tentang Kepolisian tentang perlindungan HAM melalui transparansi penyidikan dalam pemberian SP3 tersebut. Hal tersebut dapat dilakukan beberapa upaya pada faktor eksternal yang ada, antara lain sebagai berikut: Meningkatkan sosialisasi tingkat pemahaman terhadap perlindungan HAM; Meningkatkan sosialisasi pelaksanaan SP3; dan meningkatkan kerjasama dengan Pemerintah Daerah setempat.

\section{Simpulan}

Aparat kepolisian dalam melakukan penyidikan khususnya penyidik harus memperhatikan hak asasi tersangka, kurangnya pemahaman terhadap peraturan perundang-undangan yang berlaku dapat mengakibatkan pelanggaran terhadap hak asasi tersangka, upaya hukum yang dapat dilakukan oleh tersangka jika hak asasi manusianya dilanggar adalah mengajukan permohonan perlindungan hukum yang dilakukan tersangka, mengajukan permohonan gelar perkara serta upaya hukum Praperadilan. 
Pemahaman dan pengetahuan para penyidik yang ada hanya sebagian yang mengetahui secara rinci dan konkrit terhadap landasan hukum yang berkaitan dengan proses penyidikan memberikan sebagai upaya akuntabilitas dan transparansi serta sebagai upaya perlindungan HAM tersangka tidak secara mutlak diketahui oleh penyidik sebagai penegak hukum yang seharusnya mengetahui tugas dan fungsi pokok kepolisian yang dimana dalam fungsinya sebagai penegak hukum harus totalitas melindungi, mengayomi dan melayani hak dari masyarakat sebagai perlindungan HAM maka secara jelas dalam pelaksanaan Undang-Undang Kepolisian tidak secara mutlak dan jelas dalam pemahaman dan pengetahuan landasan hukum serta HAM tersebut yang harus dimiliki setiap penegak hukum yang berada di Polres sidoarjo.

\section{Daftar Pustaka}

Devlin, Patrick. 1966. The Criminal Prosecution In England. London. Oxford University Press.

Siregar, Bismar. 1983. Hukum Acara Pidana. Jakarta.

Undang-Undang Republik Indonesia Nomor 39 Tahun 1999 tentang Hak Asasi Manusia.

Widhayanti, Erni. 1988. Hak-Hak Tersangkal Terdakwa di Dalam KUHAP. Yogyakarta.

Wignyosebroto, Soetandyo. 1995. Sebuah Pengantar Ke Arah Perbincangan Tentang Pembinaan Penelitian Hukum. Jakarta. PJP II Departemen Kehakiman. 